\title{
LIFE HISTORY AND ECOLOGY OF ACRONEURIA CÄROLINENSIS (BANKS) IN PANTHER CREEK, NICHOLAS COUNTY, WEST VIRGINIA (PLECOPTERA: PERLIDAE)*
}

\author{
By D. A. Schmidt and D. C. TARTer \\ Department of Biological Sciences \\ Marshall University \\ Huntington, WV 25701
}

\section{INTRODUCTION}

Life history information is important to sampling techniques and taxonomy, production, feeding, bioassay, environmental disturbance and management studies. There is a basic lack of life history information that is needed by researchers and resource managers (Rosenberg, 1979).

Stoneflies are an important part of the stream ecosystem and are useful as water quality indicators. Few studies concerning the life histories of Acroneuria spp. have been carried out. Siegfried and Knight (1978) studied the life history of Acroneuria (Calineuria) californica Banks. Most other ecological data has been limited to $A$. abnormis and $A$. lycorias and concentrates on specific areas such as food habits, drift and predator-prey relations.

The objective of this investigation was to describe the life history of Acroneuria carolinensis with specific reference to: 1) naiad age and growth, 2) sex ratio, 3) food preference and 4) emergence.

\section{TAXONOMY AND DisTRIBUTION}

Illies (1966) presented a review of the taxonomic changes of Acroneuria carolinensis. Acroneuria carolinensis was first described as a new species by Banks (1905) as Perla carolinensis from Black Mountain, North Carolina. In 1918, Navas placed it in another genus calling the insect Nostura carolinensis. Ricker (1935) assigned new nomenclature and designated the insect as Acroneuria custae. Claassen (1940) restored the specific name thus recognizing Acroneuria carolinensis as valid.

*Manuscript received by the editor August 5, 1985 
Acroneuria carolinensis has been recorded from 11 states and three Canadian provinces. It ranges from Manitoba, Ontario and Quebec in southern Canada to Tennessee and South Carolina in the United States (Peckarsky, 1979).

\section{Materials AND MethodS}

Panther Creek originates in Nicholas County, $31 \frac{1}{2}$ miles $(5.6 \mathrm{~km})$ southeast of the Greenbrier County line, near Saxman, West Virginia at an elevation of 3000 feet $(914 \mathrm{~m})$. Panther Creek flows northward, emptying into the Gauley River at an elevation of 820 feet $(250 \mathrm{~m})$; it has a total fall of 1180 feet $(360 \mathrm{~m})$ and a total length of 9.6 miles $(15.4 \mathrm{~km})$. The drainage basin area is 16.88 square miles $\left(43.7 \mathrm{~m}^{2}\right)$ (Reger, 1921).

The study area is located along Route $39,13.7$ miles $(22.1 \mathrm{~km})$ west of the junction of Routes 19 and 39 at Summersville, at an elevation of 2200 feet $(671 \mathrm{~m})$. Collections were made in a riffle area 161 feet $(49 \mathrm{~m})$ below a concrete dam. The riffle was 36 feet $(11 \mathrm{~m})$ long and had an average width of 25.6 feet $(7.8 \mathrm{~m})$. Substrate consists of rocks with an approximate size range of 6 to 18 inches ( 15 to $46 \mathrm{~cm}$ ) in diameter.

Qualitative samples were collected monthly from December 1984 to November 1985. After disturbing the substrate, a fine meshed dredge (mesh size: $4 \mathrm{~mm}$, December-May; $1 \mathrm{~mm}$, June-November) was held immediately below the disturbed area to collect the drifting naiads. Contents of the dredge were emptied into a white enamel pan to facilitate sorting. Naiads were immediately killed and preserved in 70 percent ethyl alcohol.

Temperature of the stream was recorded monthly using a Fisher instantaneous thermometer. During the emergence period, temperature was recorded weekly.

Water chemistry was measured monthly using a Hach chemical kit (Model AL-36B). Dissolved oxygen, carbon dioxide, hardness, alkalinity and $\mathrm{pH}$ were measured in the field. All variables were measured in $\mathrm{mg} / \mathrm{l}$ except for $\mathrm{pH}$.

Total length (excluding antennae and cerci) was measured by placing the naiad on a plastic millimeter ruler and viewing under a binocular dissecting scope. Naiads were measured to the nearest 0.5 $\mathrm{mm}$ and placed in $1 \mathrm{~mm}$ class intervals. Length-frequency histo- 
grams were produced for each month. Number of age classes was determined based on the distribution of the body length.

Population range diagrams (Hubbs and Perlmutter, 1942) were used to show monthly head width variations between males and females. Early instar naiads too small to sex (usually $<6.0 \mathrm{~mm}$ ) were excluded from the analysis. Head width was measured to the nearest $0.05 \mathrm{~mm}$ using an ocular micrometer in a binocular dissecting microscope. Head width was used as a size standard because it changes least during preservation (Britt, 1953). Monthly growth rates were calculated as a percent increase in mean head width from one month to the next for males and females.

An estimation of the number of instars was calculated using the Janetschek method (Janetschek, 1967). Head width frequency histograms were produced for all collections combined. A trend-line for population growth was then calculated using a gliding mean over five successive class frequencies at a time. Gliding means were then subtracted from the frequency for each size class. These periodic maxima and minima were ploted and positive peaks were counted to determine number of instars.

Sex of naiads was determined by examining the posterior margin of the 8th abdominal sternite. A chi-square test was performed on 72 males and 152 females. Deviation from the expected 1:1 sex ratio was tested at the 0.05 confidence level.

Naiad food preference was determined by examining the contents of the foregut. Twelve foreguts were analyzed each month. After the foreguts were removed by dissection, contents of the foregut were gently scraped onto a glass slide and examined under a binocular dissecting scope. Food items were sorted and identified to the lowest taxonomic unit possible. Taxa, number of taxa per foregut and number of foreguts with the item were recorded. The mean number of a particular taxon per foregut and the percentage of foreguts in which that taxon occurred (percent frequency of occurrence) were calculated on a monthly and seasonal basis.

Using a Ward ultraviolet light trap (8 watts), an attempt was made to collect emerging adults at the study area. On 31 May 1984, the trap was set up from 10:00 to 12:00 p.m. During May and June, the banks of Panther Creek were searched for exuviae to determine the emergence period. Distance of exuviae from the stream bank and type of substrate on which they were found were recorded. 


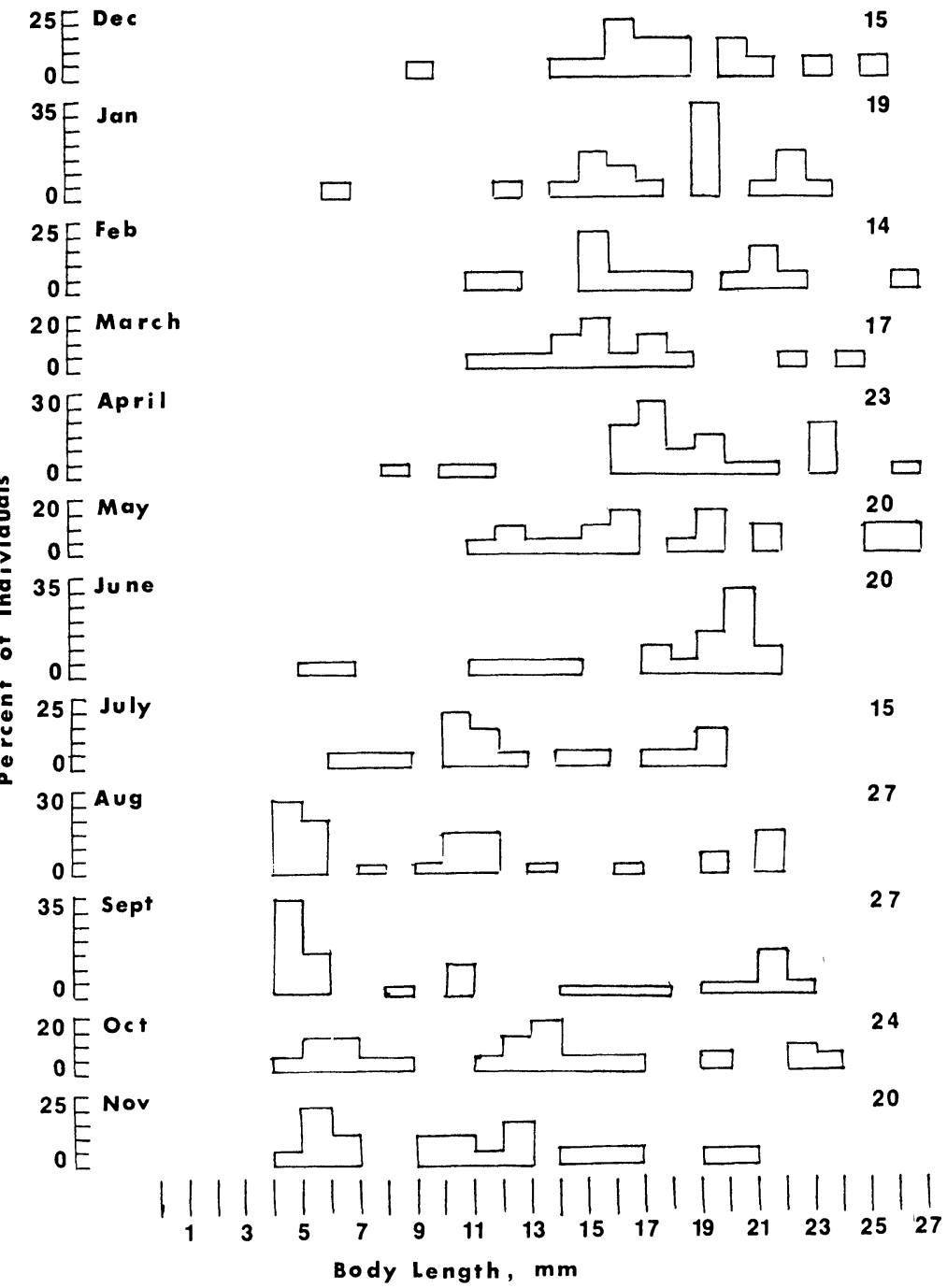

Figure 1. Length-frequency histograms showing monthly distribution of Acroneuria carolinensis naiads. 
Fecundity was determined by direct egg count. Eggs were dissected out from 19 adults. They were placed in a syracuse watch glass and counted under a binocular dissecting scope. Regression analysis was used to determine the relationship between total body length and number of eggs produced. A correlation coefficient (r) was calculated to determine the strength of the relationship.

The diameter and length of 125 eggs from five adults were measured using an ocular micrometer in a binocular dissecting scope. Eggs were measured to the nearest $0.01 \mathrm{~mm}$. Average egg size was calculated.

\section{Results AND Discussion}

Stream environment. The mean water temperature at Panther Creek during the study period was $8.3 \mathrm{C}$. The temperature ranged from 0.0 in January to $16 \mathrm{C}$ in June. During emergence studies, a high temperature of $17 \mathrm{C}$ was recorded on 8 June 1984.

Dissolved oxygen was high, ranging from 7 to $13 \mathrm{mg} / \mathrm{l}(\overline{\mathrm{X}}=9.4$ $\mathrm{mg} / \mathrm{l})$. Carbon dioxide ranged from 10 to $85 \mathrm{mg} / \mathrm{l}$, with a mean of $61.5 \mathrm{mg} / \mathrm{l}$. Alkalinity ranged from 0.0 to $102.6 \mathrm{mg} / \mathrm{l}(\overline{\mathrm{X}}=29.9 \mathrm{mg} / \mathrm{l})$ during 1982, according to Pettry (1983). Total hardness ranged from 34.2 to $224.9 \mathrm{mg} / \mathrm{l}(\overline{\mathrm{X}}=122.8 \mathrm{mg} / \mathrm{l})$. The $\mathrm{pH}$ had a mean value of 6.9 and ranged from 6.3 to 7.2 .

Length-frequency histograms. Length-frequency analysis indicated a two-year life cycle (Figure 1). Body length ranged from 3.5 to $26.0 \mathrm{~mm}$. The largest naiads were collected in February, April and May. Larger naiads were absent following the 20 May collection, when emergence had occurred. There was approximately an 11 week egg development period before recruitment of the new age class. The smallest and earliest naiads were first collected in late August. The existence of a $6 \mathrm{~mm}$ naiad in January suggested some evidence that a three-year life cycle may be possible. Absence of additional naiads of this size could have been due to the larger mesh size dredge used during the winter collections.

Harper and Magnin (1969) suggested three-year life cycles for $A$. abnormis and $A$. lycorias. They also indicated that the number of naiads collected was too small to make a definite conclusion. Sheldon (1969) reported a life cycle of three years for Calineuria californica at an elevation of $2200 \mathrm{~m}$. Heiman and Knight (1975) and Siegfried and Knight (1978) both suggested a two-year life cycle at 
lower elevation for C. californica. Allen and Tarter (1985) reported a two-year life cycle for Eccoptura xanthanes (formerly $A$. xanthanes).

Growth. Population range diagrams (Figure 2) showed a wide range in head width. The largest female head width was $6.22 \mathrm{~mm}$ and occurred in October. The largest male head width was $5.07 \mathrm{~mm}$ and occurred in December. Females exhibited greater mean head widths than males (Figure 2). Males exhibited greatest growth in August (12\%) and October (17\%). Growth of females was greatest in August (28\%) and January (13\%). The smallest immatures were first collected in August and had their greatest growth in October (21\%). Following emergence there was a marked decrease in mean head width for males in July (26\%) and females in June (30\%). The population showed a sharp decrease in mean head width in August (48\%). This decrease coincided with the recruitment of a new age class.

Calineuria californica exhibited its greatest growth in spring when the stoneflies were still small (Siegfried and Knight, 1978). Growth declined with an increase in size. In this study $C$. californica showed an egg diapause and early instars were not collected until February. In laboratory growth studies with $C$. californica, the greatest growth occurred in the summer, while the least occurred in the winter (Heiman and Knight, 1975).

The Janetschek method (Janetschek, 1967) indicated that $A$. carolinensis naiads underwent 25 instars (Figure 3a and 3c). A general growth trend using gliding means is shown in Figure $3 \mathrm{~b}$.

Sex ratio. A chi-square test was applied to 72 male and 152 female $A$. carolinensis naiads. A significant deviation from the expected 1:1 ratio was observed at the 0.05 confidence level.

Foregut analysis. Of the 144 foreguts examined, 78 (54\%) contained food items. The highest percentage of empty foreguts occurred in April (75\%). On a seasonal basis the percent of empty foreguts never exceeded 50 percent.

Acroneuria carolinensis naiads were carnivorous, with Diptera $(\overline{\mathrm{X}}$ $=6.4, \% \mathrm{FO}=19.4)$, plecopterans $(\overline{\mathrm{X}}=1, \% \mathrm{FO}=15.9)$, ephemeropterans $(\overline{\mathrm{X}}=1, \% \mathrm{FO}=12.5)$ and trichopterans $(\overline{\mathrm{X}}=1.3, \% \mathrm{FO}=$ 5.5) as the most important food items. Diptera was represented by larval chironomid midges. Plecopterans found in the foregut included members from the families Capniidae, Leutridae, Nem- 


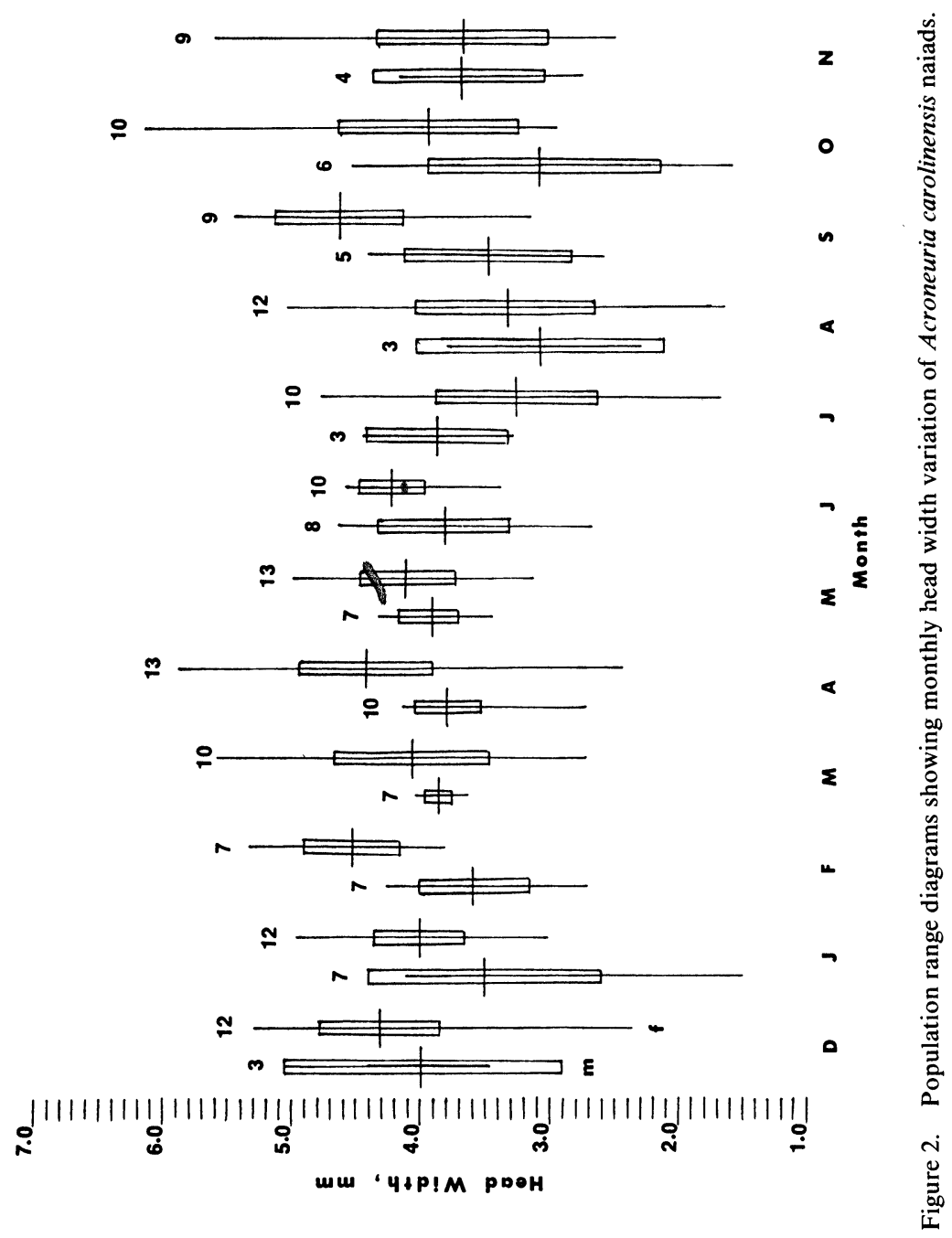


ouridae, Taeniopteryidae and Perlodidae. Ephemeropterans included representatives from the genera Ephemerella, Epeorus, Cloeon, Stenonema and a member from the family Baetidae. Trichopterans included representatives of the genera Glossosoma, Hydropsyche and Cheumatopsyche.

Results of monthly foregut analysis are presented in Figure 4. Plecopterans and ephemeropterans made up the principle components of the diet throughout the year. Dipterans became important in the winter and summer, while trichopterans were most important in the summer. Naiads fed most during the winter months with an average of 5.0 food items/stonefly. They fed least during the spring and fall with an average of 1.1 food items/stonefly each season. Siegfried and Knight (1976a, 1976b) and Sheldon (1969) reported dipterans, trichopterans and ephemeropterans as the most important food items for C. californica. Sheldon (1969) found that ephemeropterans were a regular component of $C$. californica's diet and dipterans were important in the winter and summer. Siegfried and Knight (1976a) stated that dipterans were the most important and consistent food item for C. californica. Siegfried and Knight (1976b) found that $C$. californica naiads showed no preference for a particular prey and would eat anything available. They also reported a significant correlation between gut diversity and benthic diversity. Sheldon (1969) stated that food consumption was low in the summer. In a laboratory study, Heiman and Knight (1975) found that $C$. californica had its greatest food consumption in the summer, with minimal feeding in the winter, at normal environmental temperatures. Johnson (1981) reported that dipterans and trichopterans were the primary diet for $A$. abnormis. The diet was supplemented with ephemeropterans.

Phoresy. Larvae of a chironomid midge were observed living phoretically with Acroneuria carolinensis naiads. The midges occurred on the prothorax or just beneath the mesothoracic wing pad. The phoretic attachment occurred on nine of 241 (3.7\%) naiads examined. Dosdall and Mason (1981) reported the chironomid Nanocladius (Plecopteracoluthus) branchicolus living phoretically on $A$. lycorias. They reported varied percentages of the number of stoneflies bearing the chironomids. The percentages of phoretic cases ranged from $10-50$ percent.

Rearing and emergence. The attempt to collect emerging adults on 31 May 1984 was unsuccessful. Exuviae were collected up to 4.6 

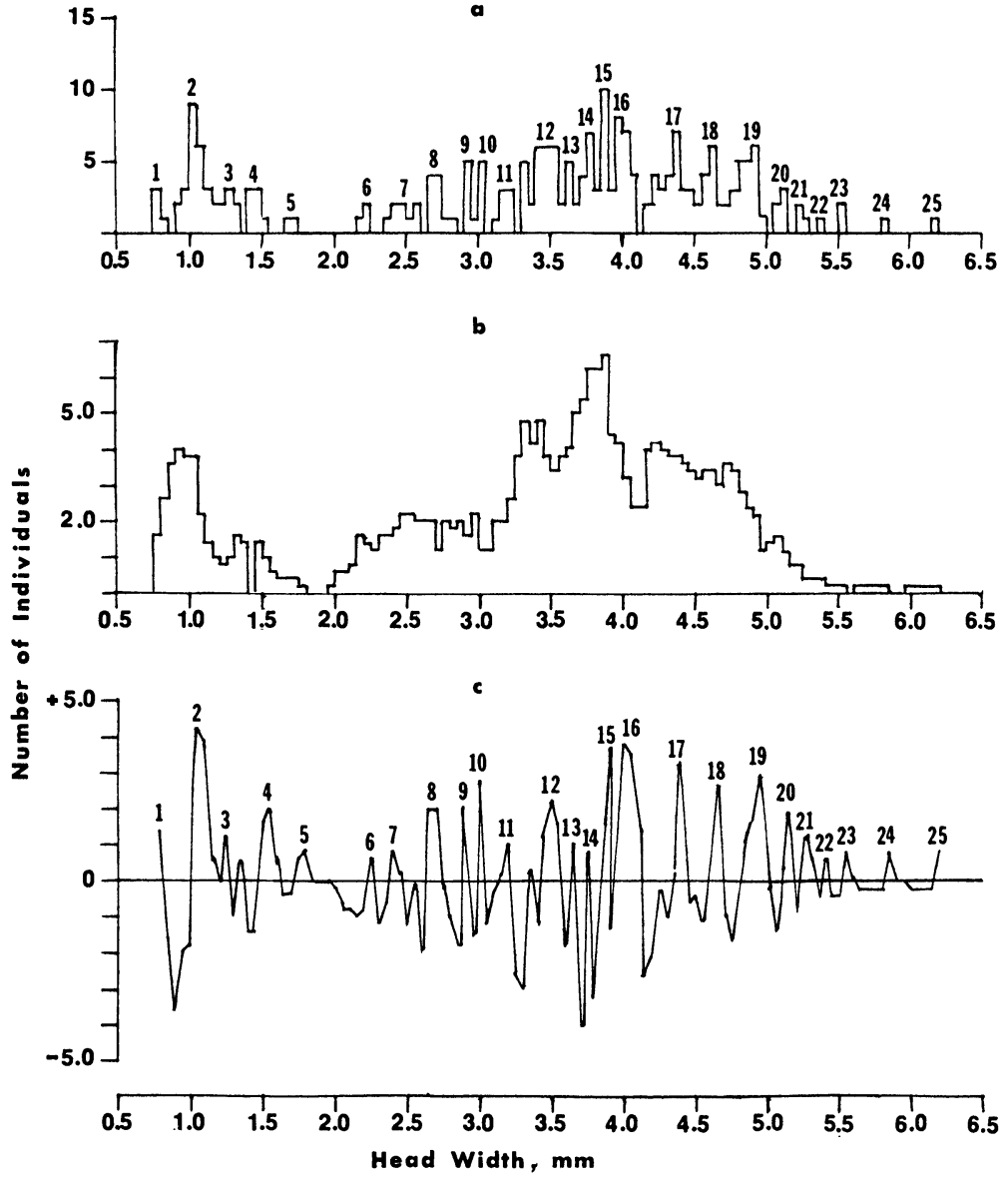

Figure 3. Growth rates of Acroneuria carolinensis naiads from Panther Creek, Nicholas County, West Virginia, 1983-1984: a) frequency of size classes; b) trendline of the population, calculated by gliding means over five successive size-class frequencies at a time; c) periodicity of maximum frequency of size.

$\mathrm{m}$ from the water surface. They were found clinging to sand, rocks, rhododendron stems and moss. Based on the number of exuviae collected (33), peak emergence was on 8 June 1984; emergence lasted three weeks. The first exuvium was collected on 1 June and the last on 16 June. Emergence peaked with a corresponding peak in 

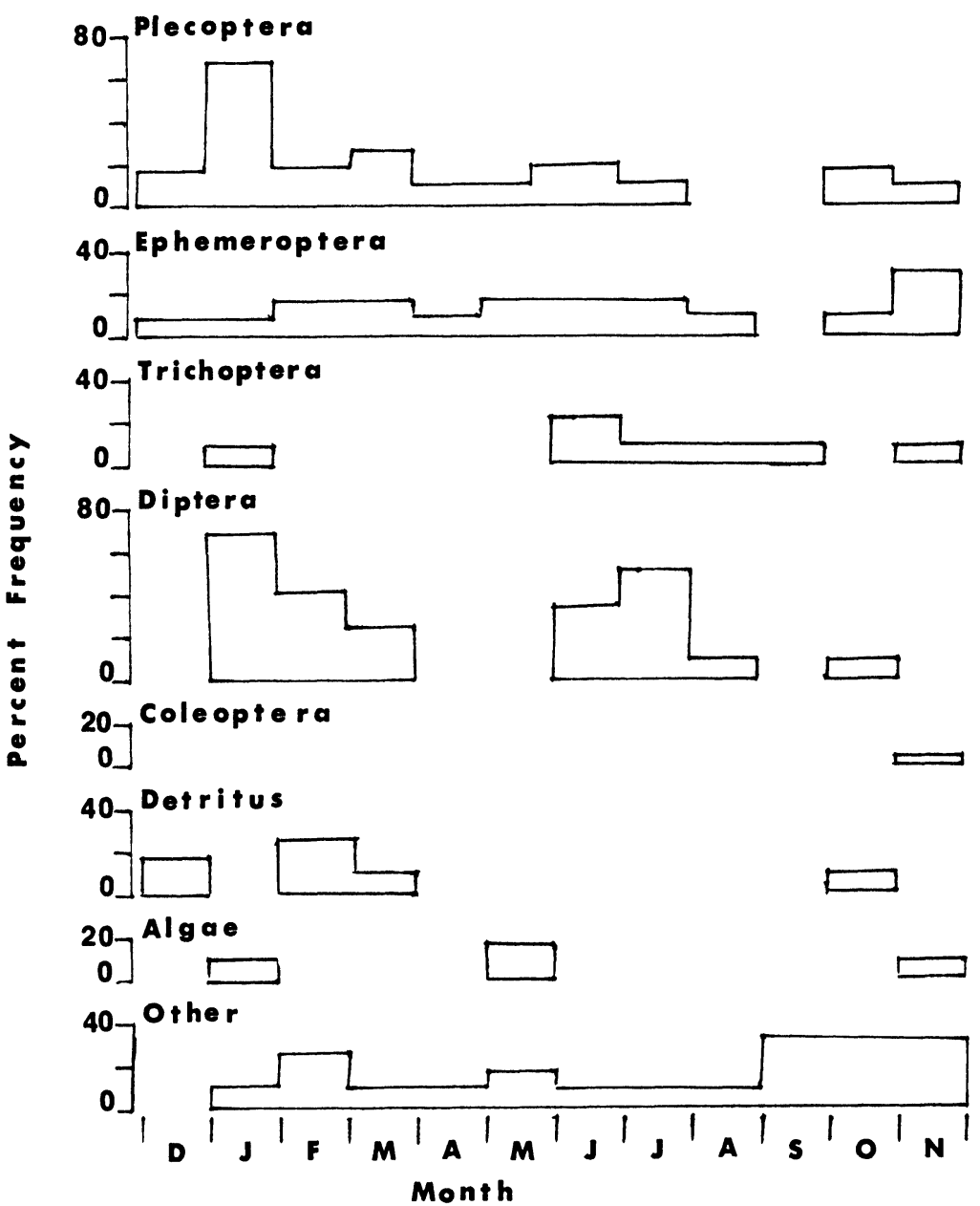

Figure 4. Percentage frequency of food items in foreguts of Acroneuria carolinensis naiads each month.

temperature $\left(17^{\circ} \mathrm{C}\right)$ (Figure 5). Mingo (1983) reported A. carolinensis to be in flight from 12 June to 3 August in Maine. Flight periods for other Acroneuria spp. recorded by Mingo (1983) were: $A$. abnormis, 10 June to $14 \mathrm{July;} A$. arenosa, 30 June to 3 August; A. lycorias, 10 July. Kondratieff and Despins (1983) reported the 
following flight periods for Acroneuria sp. and related genera from Virginia: $A$. arenosa, late June to early July; $A$. abnormis, throughout June; Eccoptura xanthanes, late May through mid-July. Allen and Tarter (1985) reported E. xanthanes emerged from 11 June to 14 July in Kentucky.

In a separate study, $A$. carolinensis naiads and adults were to be collected at Panther Creek in the spring of 1985. On 25 May no final instar naiads were collected. On 2 June a single final instar naiad was found after two hours of sampling. These findings suggested that emergence had taken place in mid-May, three weeks earlier than 1984 emergence. The weather in April 1985 was unseasonably warm, and perhaps induced early emergence. Harper and Pilon (1971) studied the emergence of A. abnormis for three years (1958, 1959, 1966). They found little temperature difference between the emergence curves, but cooler temperatures in 1958 had delayed emergence for two weeks.

Fecundity. Of the 19 adults examined, only seven contained mature eggs. Therefore, mature eggs and immature eggs of comparable size were counted. Direct egg count resulted in a range of 10 to 800 eggs $(\bar{X}=239)$ per female. There was little correlation between body length and number of eggs $(\mathrm{r}=0.56)$.

Egg size. Acroneuria carolinensis eggs were oval in shape. Mean length was $0.43 \mathrm{~mm}$ (range $0.38-0.48 \mathrm{~mm}$ ), mean diameter was 0.33 $\mathrm{mm}$ (range $0.29-0.38 \mathrm{~mm}$ ). Stark and Gaufin (1976) provided electron micrographs of the eggs and gave detailed descriptions. From the material examined by Stark and Gaufin (1976), two types of ova were found. They suspect two closely related species are involved and suggested additional studies of the complex.

\section{SUMMARY}

The life history and ecology of Acroneuria carolinensis from Panther Creek, Nicholas County, West Virginia were studied from December 1983 to November 1984. Length-frequency distribution indicated a two-year life cycle. The largest naiads $(26.0 \mathrm{~mm})$ were collected in February, April and May. Females and males exhibited greatest growth in August (28\%) and October (21\%), respectively. Naiads underwent 25 instars. A chi-square test applied to 72 males and 152 females showed a deviation ( 0.05 confidence level) from the expected 1:1 sex ratio. Naiads were carnivorous in their feeding 


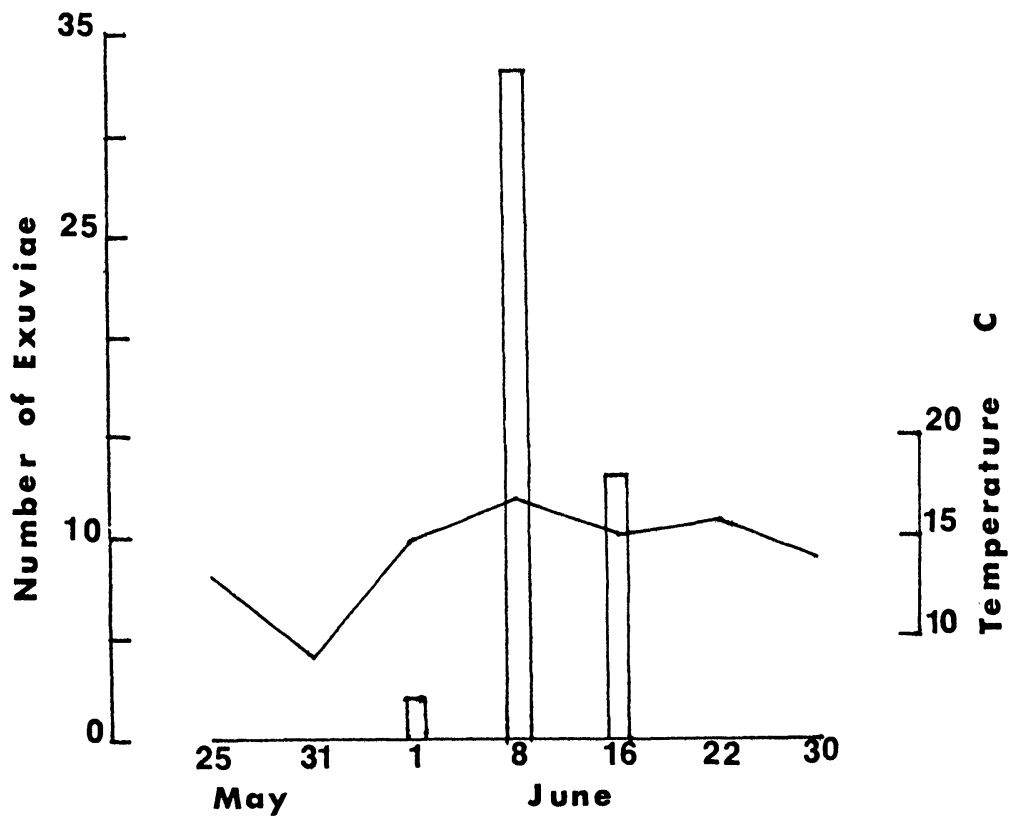

Figure 5. Naiad exuviae collected during May and June, 1984, showing yearly pattern of emergence of Acroneuria carolinensis.

habits. Plecopterans $(\overline{\mathrm{X}}=1, \% \mathrm{FO}=15.9)$ and ephemeropterans $(\overline{\mathrm{X}}$ $=1, \% \mathrm{FO}=12.5$ ) made up the principle components of the diet. Dipterans were important components in the winter and summer, while trichopterans became important in the summer. A phoretic relationship between $A$. carolinensis naiads and a chironomid midge was observed on 3.7 percent of the naiads examined. Emergence was between 1 June and 16 June; peak emergence occurred on 8 June 1984. Direct egg counts for adult females ranged from 10 to 800 eggs $(\overline{\mathrm{X}}=239)$ per female. There was little correlation between body length and number of eggs $(\mathrm{r}=0.56)$. Mean egg length was $0.43 \mathrm{~mm}$ (range $0.38-0.48$ ) and mean egg diameter was $0.33 \mathrm{~mm}$ (range $0.29-0.38)$.

\section{ACKNOWLEDGMENTS}

The authors are especially thankful to the following persons for help in this investigation: Dale Adkins, Dean Adkins, Allan Brant, 
Creda and Jim Meadows, Amy Messinger, Brian Reeder and Thomas Weaks. Special thanks to Vickie Crager for typing the manuscript.

\section{Literature Cited}

Allen, B. L. AND D. C. TARTer.

1985. Life history and ecology of Eccoptura xanthanes (Newman) (Plecoptera: Perlidae) from a small Kentucky stream. Proc. Ky. Acad. Sci. (IN PRESS)

BANKS, N.

1905. Descriptions of new species of neuropterous insects from the Black Mountains, N. C. Am. Mus. Nat. Hist. Bul. 21: 215-218.

BRITT, N. W.

1953. Differences between measurements of living and preserved aquatic insects caused by injury and preservatives. Ecology 34: 802-803.

Claassen, P. W.

1940. A catalogue of the Plecoptera of the world. Mem. Cornell Univ. Agric. Exp. Stn. 232: 1-235.

Dosdall, L. M. and P. G. Mason.

1981. A chironomid (Nanocladius branchicolus: Diptera) phoretic on a stonefly (Acroneuria lycorias: Plecoptera) in Saskatchewan, Canada. Can. Entomol. 113: 141-148.

Harper, P. AND E. MAGNin.

1969. Cycles vitaux de quleques Plecopteres de Laurentides (insectes). Can. J. Zool. 47: 483-494.

Harper, P. AND J. C. Pilon.

1971. Annual patterns of emergence of some Quebec stoneflies. Can. J. Zool. 48: 681-694.

Heiman, D. R. And A. W. Knight.

1975. The influence of bioenergetics of the carnivorous stonefly Acroneuria californica Banks (Plecoptera: Perlidae). Ecology 56: 105-116.

Hubbs, C. L. and A. Perlmutter.

1942. Biometric comparison of several samples, with particular reference to racial investigations. Amer. Natur. 76: 582-592.

ILLIES, $\mathbf{J}$.

1966. Katalog der rezenten Plecoptera. Das Tierreich, Berlin, 82: I-XXX: $1-632 \mathrm{pp}$.

JANETSCHEK, $\mathrm{H}$.

1967. Growth and maturity of the springtail, Gomphiocephalus hodgsoni Carpenter, from South Victoria and Ross Island, p. 295-305 in Entomology of Antarctica. Antarct. Res. Ser. 10.

JoHNSON, J. H.

1981. Food habits and dietary overlap of perlid stoneflies (Plecoptera) in a tributary of Lake Ontario, NY, USA. Can. J. Zool. 59: 2030-2037. 
KondratiefF, B. C. AND J. I. Despins.

1983. Seasonal flight patterns of Plecoptera from North Otter Creek, Virginia. Ent. News 94: 41-44.

Mingo, T.

1983. An annotated checklist of the stoneflies (Plecoptera) of Maine. Ent. News 94: 65-72.

Navas, L.

1918. Plecopteros. In: Neuropteros neuvoso poco conocides. Mem. R. Acad. Cienc. Artes Barcelona. 14: 5-13 (341-349).

Peckarsky, B. L.

1979. A review of the distribution, ecology and evolution of North American species of Acroneuria and six related genera (Plecoptera: Perlidae). J. Kans. Entomol. Soc. 52: 787-809.

Pettry, D. K.

1983. Ecological life history of Baetisca carolina Traver in Panther Creek, Nicholas County, West Virginia (Ephemeroptera: Baetiscidae). Unpublsh. Masters Thesis. Marshall University. $85 \mathrm{pp}$.

REgER, D. B.

1921. West Virginia Geological Survey. County reports, Nicholas County. Wheeling News and Lithographing Co., Wheeling, West Virginia. 847 pp.

RICKER, W. E.

1935. Descriptions of three new Canadian perlids. Can. Ent. 67: 197-201.

Rosenberg, D. B., ED.

1979. Freshwater benthic invertebrate life histories: Current research and future needs. J. Fish. Res. Bd. Can. 36: 289-345.

SHELdon, A. L.

1969. Size relationships of Acroneuria californica and its prey. Hydrobiologica 34: $85-94$.

Siegfried, C. A. AND A. W. KNight.

1976a. Prey selection by a setipalpian stone fly nymph Acroneuria (Calineuria) californica Banks (Plecoptera: Perlidae). Ecology 57: 603-608.

1976b. Trophic relations of Acroneuria (Calineuria) california (Plecoptera: Perlidae) in a Sierra foothill stream. Environ. Entomol. 5: 575-581.

1978. Aspects of the life history and growth of Acroneuria (Calineuria) californica in a Sierra foothill stream. Ann. Entomol. Soc. Am. 71: 149-154.

Stark, B. P. and A. R. Gaufin.

1976. The Nearctic species of Acroneuria (Plecoptera: Perlidae). J. Kans. Ent. Soc. 49: 221-253. 

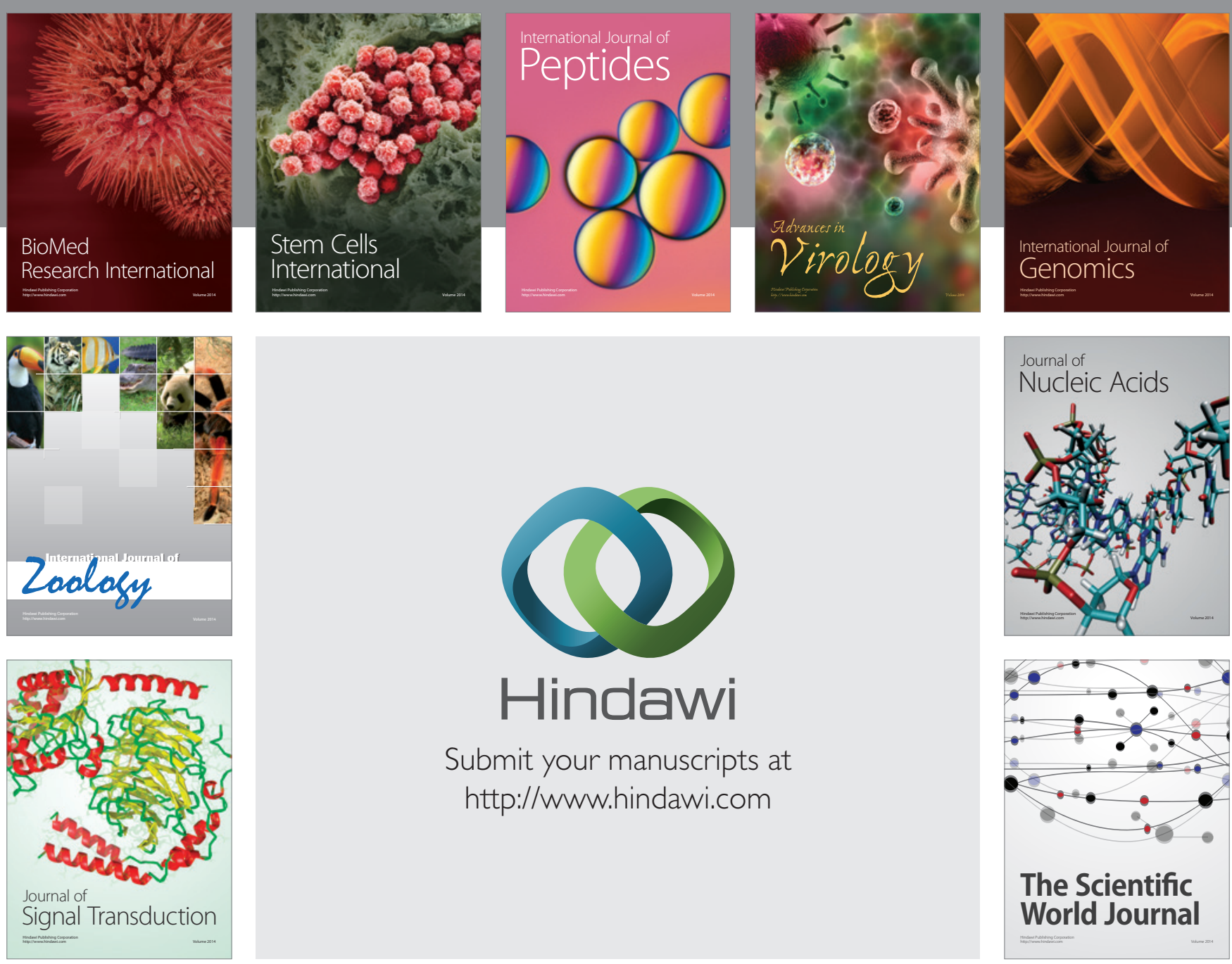

Submit your manuscripts at

http://www.hindawi.com
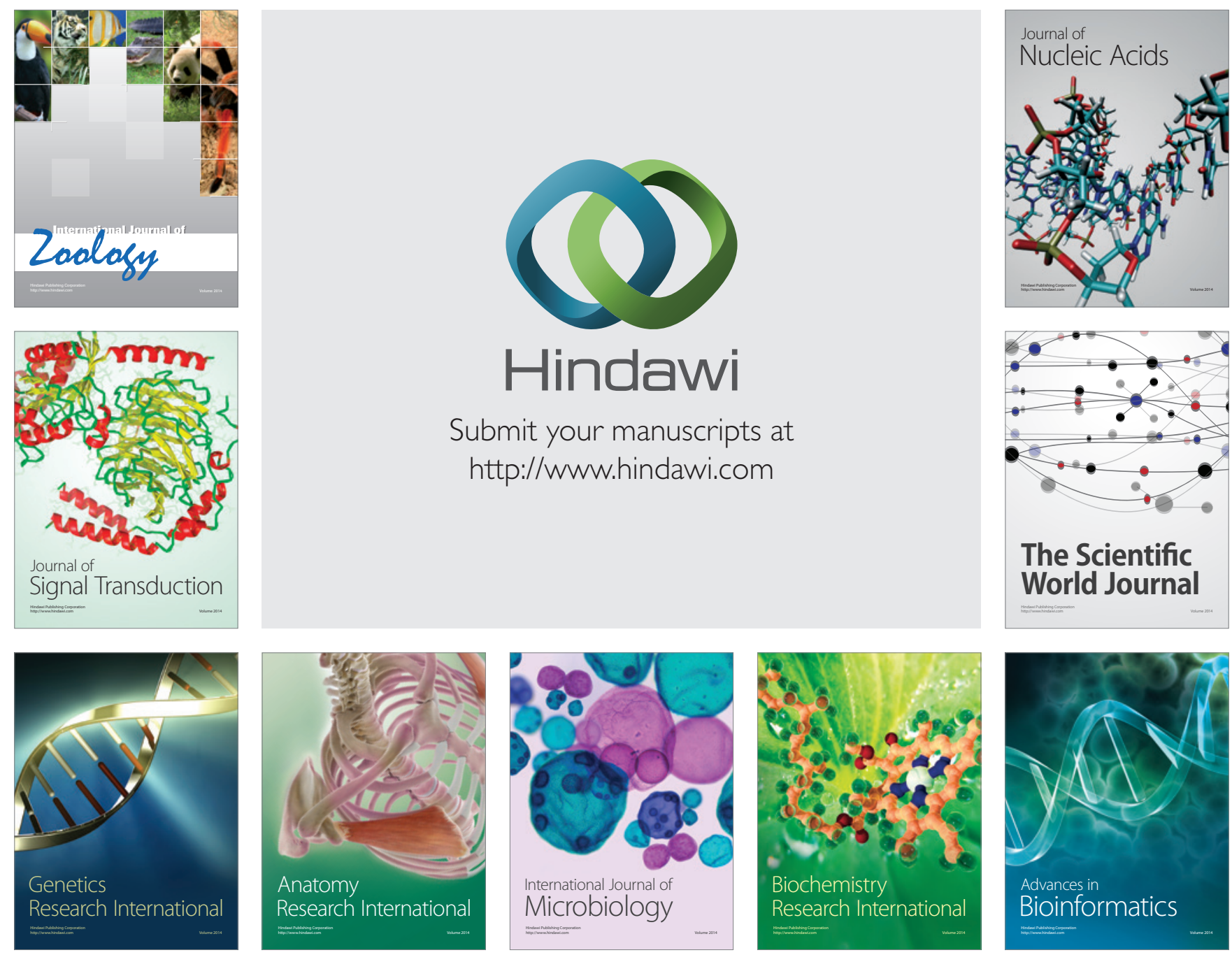

The Scientific World Journal
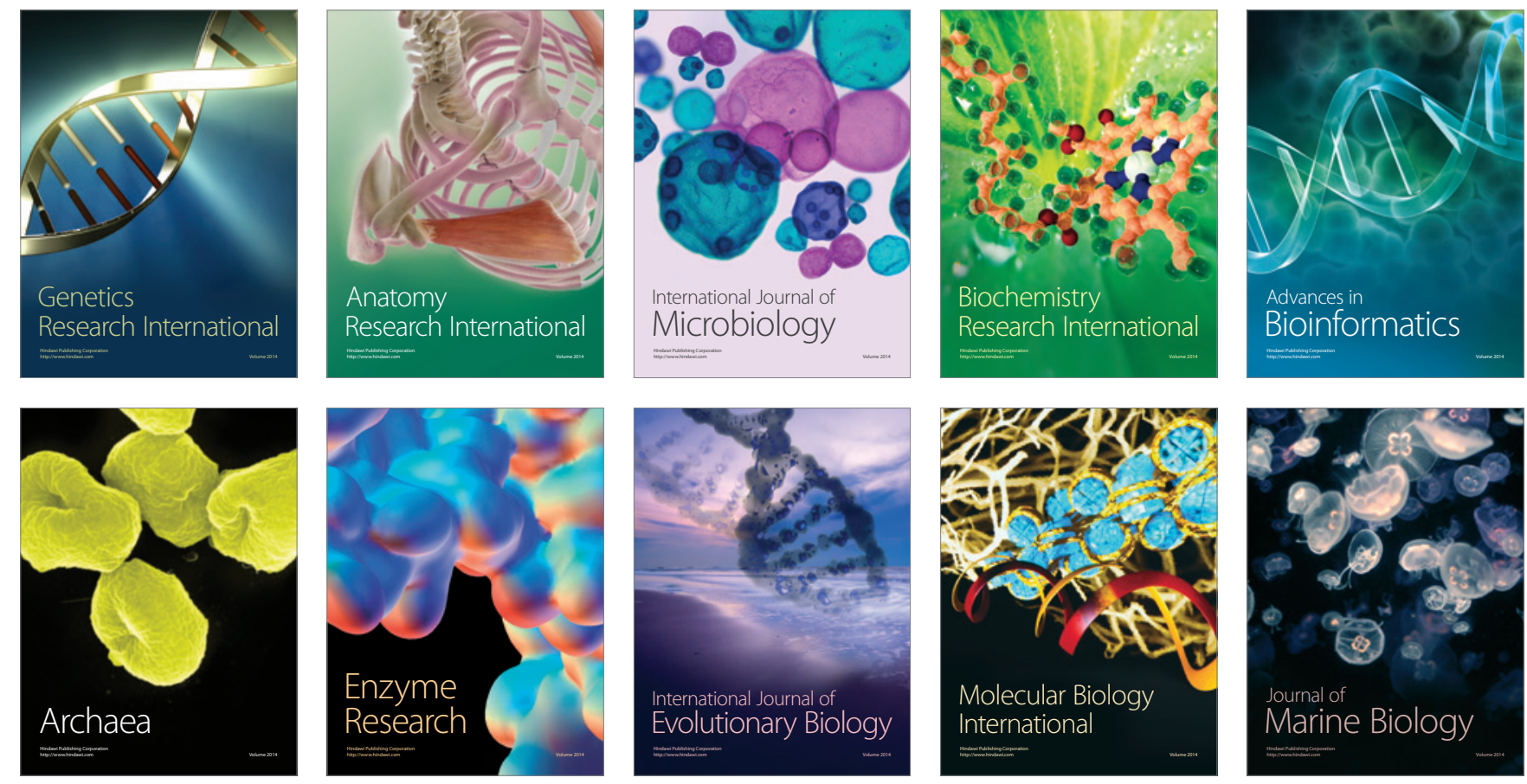